\title{
The Other Version of the Story: National Identity in the Modern Palestinian Novel
}

\begin{abstract}
By Ibrahim A. El-Hussari*
This survey article explores the parameters of the Palestinian national identity as represented in the fictional world of a number of Palestinian narratives written in Arabic and other languages over the past hundred years. More specifically, the article traces the dramatic transition of identity formation from personal discomfiture with the breakdown of self-interested enterprises to mass awareness of the existential threat posed by the Zionist Movement Project ${ }^{l}$ against the national aspiration of the Palestinian people in Palestine as their only homeland. The threat in question was the consequence of the militant immigrant Jewish settlers who infiltrated into Palestine in successive waves of European Jewish immigrants in the wake of Sykes-Picot Agreement ${ }^{2}$ and Balfour Declaration. ${ }^{3}$ Ever since the coming out of the first Arab Palestinian novel, al-Wareth, ${ }^{4}$ the issue of identity has been steadily gaining a central place in the Palestinian narrative art, irrespective of the stance and angle of vision from which the story is told. As a form of art of fiction, the Palestinian novel says something about the loss or distortion of the Palestinian national identity through a deliberate, programmed erosion of individual and collective memories, including history and popular culture. This purposeful erosion has been consistently the target of the single-handed historical narrative provided by the official annals of Israel $l^{5}$ as an immigrant settlers' colonial project replacing the state of Palestine on the world map. The Palestinian narratives under study bring out into the open the long-denied version of the truth by unfolding the hidden narrative account of the Palestinian national identity for the fullness of history.
\end{abstract}

Keywords: Identity, Palestinian, Hebrew, narratives, memory, Zionist project

\section{Introduction}

Since the creation of the state of Israel in Palestine in 1948, the Middle East has been plagued with endless rounds of warfare, violence and instability. As a result of this weird situation, the Palestinians have been paying heavily in blood and property for voicing themselves as a people with legitimate birthrights and aspirations in their own homeland and in exile. One of the channels of expressing

\footnotetext{
* Professor of English \& Cultural Studies, Lebanese American University, Lebanon.

${ }^{1}$ Zionism was created by Theodor Herzl in central and eastern Europe in 1896 as a national Jewish movement in search of a homeland for the Jews in Diaspora. Although offered land in Africa and Latin America (Uganda and Argentina, for example) by colonial Europe, the Zionist leaders settled on Palestine as the Promised Land. Palestine and the Palestinian population then were part of the Ottoman Empire.

${ }^{2}$ Sykes-Picot Agreement, aka Asia Minor Agreement, was a secret memorandum of understanding concluded on May 9, 1916 between Great Britain represented by Sir Mark Sykes and France represented by Georges Picot to partition the Asian region of the Ottoman Empire which then included Greater Syria (Lebanon, Palestine, and Jordan) and Iraq. The agreement came into effect when it was officially abrogated by the Allies at the San Remo Conference in April 1920, Mandate for Palestine being conferred upon Britain.

${ }^{3}$ On November 2, 1917 Lord Arthur James Balfour, the foreign secretary of Great Britain issued a declaration in the form of a letter addressed to Baron Walter Rothschild but delivered through Chaim Weizmann, a Zionist activist, expressing the British support for creating a "Jewish national home" in Palestine.

${ }^{4}$ al-Wareth (The Inheritor) is the first Palestinian novel written by Khalil Baydas, both journalist and translator, and published in 1920. See also Nasser-eddine el-Assad, Lectures on Khalil Baydas: Pioneer of the Arabic Narrative in Palestine, Cairo: Institute of Higher Arabic Studies, The Arab League, 1963.

${ }^{5}$ Israel is the immigrant state created by the militant Jewish settlers in Palestine in 1948, following the forced expulsion of 800,000 civilian citizens who lost home and became refugees in various parts of the world. This state was officially created and recognized in a resolution issued by the General Assembly of the United Nations same year.
} 
that voice in writing has been literature. This article tries to keep track of that voice which shapes the Palestinian national identity and aspirations through a survey study of select narratives written before and after the loss of Palestine. Hence the need for a link between history and literature for a clearer image of an intricate issue as that of the Palestinian national identity.

\section{Historical Perspective}

The Jewish-Arab existential struggle over Palestine started with the launching of the Zionist political project based on the myth of the promised land. The project was proclaimed by the first Jewish Congress held in Basle, Switzerland, in 1897. Yet, the struggle began to escalate in 1917 with the issuance of the Sykes-Picot Plan "to partition the Asiatic geographical space of the Ottoman Empire" (Said 1979: 220), only to reach its peak with the break out of violence between Jewish settlers and native Arabs in Palestine in May 1948. That violence resulted in the forced expulsion of around 800,000 Palestinian civilians (70\% of the population then) from their homeland and the creation of the State of Israel on almost $78 \%$ of historical Palestine. In his book Ethnic Cleansing of Palestine (2006), Ilan Pappe, a renowned Israeli scholar, demonstrates how ethnic cleansing in Palestine then was not a consequence of war, but rather a deliberate goal of combat for early Jewish military units led by Ben-Gurion, who had a plan conceived on March 10, 1948, that is two months before the British colonial troops pulled out from Palestine and two months before the first Arab-Israeli war broke out on May 15, 1948. The plan, ${ }^{6}$ Pappe contends, was meant to depopulate and demolish hundreds of Arab villages, thus causing an exodus of intimidated Palestinian civilians who fled their towns and villages for what they thought was a short-time safe haven in the neighboring Arab countries after which they would return home.

Since 1948, the scene has been steadily growing darker, not only for the displaced Palestinians who discovered early on that they had become refugees and had to bear with life in exile, but also for those 140,000 Palestinians who stayed on, and who have become by now a big minority in the state of Israel today (over one million, that is $20 \%$ of the entire population) assumingly posing a demographic threat to the long-standing Zionist plan to manufacture an ethnically pure Jewish state in Palestine, as Pappe argues in the same book. Jimmy Carter, the $39^{\text {th }}$ president of the United States was under no obligation as a world peace activist when he chose Palestine: Peace Not Apartheid as a challenging title of his book published in 2006. In this respect, it should not be redundant to lament all of the UN resolutions issued in favor of a peaceful settlement in Palestine and the Middle East but have been left dead wood since 1947.

\footnotetext{
${ }^{6}$ Pappe implies to Hagannah, Stern, and Irgun as the military units operating during the British Mandate for Palestine (1920-1948), and whose job was to intimidate the civilian Arab Palestinians by using military force. Ironically, those units were led by David Ben-Gurion, Manachem Begin, and Yitzhak Shamir, who would become political leaders in the wake of the creation of Israel as a state in 1948, and Israel's Prime Ministers for Labor and Likud parties respectively.
} 


\section{Literary Perspective}

In literature, more specifically narrative art, peculiar images identifying both Arab and Jewish characters cannot be overlooked. When it comes to approaching the issue of identity politics entangling the two adversary parties in Palestine under the British Mandate, literary narratives would possibly fill the gap which the historical narrative may have overlooked or distorted. In fact, the earlier Hebrew narratives, including Leon Uris's Exodus (1959) and Shamuel Agnon's Forever More (1966), did not start from scratch. Some nonHebrew fiction writers, such as Benjamin Disraeli (a former Prime Minister of England, 1868-1976) in Tancred or The New Crusade (1847) and the British novelist, George Eliot, in Daniel Deronda (1876) had already cultivated the image of the European Jew re-inventing himself and reviving an imagined social existence through a spiritual journey [he takes] to the Holy Land, in an attempt to put an end to the myth of the Shylock image of the Jew as sketched in some European literature 7 as well as that of the "wandering Jew" (Peleg 2005) who needs to belong and settle somewhere. However, the bulk of the earlier Hebrew narratives owe their substance and themes mostly to wisdom literature in the Hebrew Bible, the Talmudic tales, the Haskala, ${ }^{8}$ Hibbat Zion, ${ }^{9}$ the Aggadah, ${ }^{10}$ and the horror tales of the Russian Pogroms and the Nazi Holocaust, the hero always being either an infallible, David-like hero facing a Goliath, a wandering Jew, or an innocent pathetic victim. The merit associated with those popular tales, if any at all, is two-fold: firstly, to mitigate the Shylock image of the Jew as usurer in favor of the Jew as a victim in search of a homeland; and secondly to merge religion, language and the nation into one Hebraic mould, creating ample space for the Zionist project to nurse its political ideology in Palestine, the dreamland claimed as the only home for the homeless Jew (see Harshav 1993, Hever 2002). In almost all of those tales Palestine is described as a desert, empty and barren, and the Palestinian is stereotyped as nomadic, savage, stranger, blood avenger, and without a cause (see Theodor Herzl's Alteneuland (1902); Arthur Koestler's Thieves in the Night (1956); Leon Urus's Exodus (1958); Robert Nathan's A Star in the Wind (1962); and others).

However, this paper is in no wise a comparative literature study. It is a survey article that focuses on an anthology of Arab Palestinian works of fiction across which the issue of national identity takes shape as it moves from the personal, problematic vision undermining self interest to the public vision addressing a serious existential problem threatening to oust the Palestinian people from geography and history, from time and space.

\footnotetext{
${ }^{7}$ Reference is made to two Elizabethan plays: William Shakespeare's Merchant of Venice (1597?) and Christopher Marlow's Jew of Malta (1590?).

${ }^{8}$ Haskala is Hebrew Enlightenment.

${ }^{9}$ Hibbat Zion is Hebrew for love of Zion.
} 


\section{Arab Palestinian Narratives and Identity}

\section{The Beginnings}

Apart from traditional folk tales and other popular narratives, which were usually part of the Palestinian socio-cultural life and character for a long time, the Palestinians were also producing narrative art in the form of novels. The first Palestinian novelist ever was Khalil Baidas who wrote al-Wareth [The Inheritor] which came out in 1920, that is four years after the Sykes-Picot Agreement and three years after the Balfour Declaration. In this tale, Baidas cautioned against the Shylock-image of the Zionist project leaders who were posing a real threat to the socio-moral and economic life of the well-to-do Palestinians, at the time the Jewish waves of immigration into Palestine under the British Mandate were multiplying; and the Palestinian national uprising against such waves of immigration was widely visible. Let alone the aesthetic value of the tale, al-Wareth did not entirely respond to the historical condition behind its birth, nor did it relentlessly betray that condition; it simply positioned itself as a watchdog trying to envision what was going on, but that vision was simply defective, for the story "failed to see the full impact of the Zionist project in Palestine" (Wadi 1981: 22).

It would take forty-three years for the modern Palestinian novel to appear with the publication of Ghassan Kanafani's Rijal fil Shams (Men in the Sun) in 1963. This does not mean that the period between 1920 and 1963 brought up no Palestinian narratives at all. In fact, a lot of stories were told; however, only a few of them would implicitly depict the drama of the Palestinians whose land, property, culture and national identity were facing the most horrendous plan of extermination ever targeting a people on earth, save perhaps the native Americans, the Tasmanians, and the Armenians. Among those story-tellers were Iskandar El-Khoury, Mohammed Ezzat Darwaza, ${ }^{10}$ Gabriel Abu Sa'adi, Is'haq Mousa El-Husseini, and others. It should be noted that El-Husseini's story Muzakkarat Dajaja [Memoirs of a Mother Hen] in 1943, perhaps the most famous and widely-read narrative in the Arab World during the 1940s, dramatizes the Palestinian situation on the eve of $a l-N a k b a^{11}$ in 1948 as something pre-destined. Owing its narrative form, language and style to the Oriental literary heritage, namely the fables of Kalila wa Dimna, ${ }^{12}$ the story uses animal characters as a vehicle carrying the author's vision about life and fate where the artistic, the visionary, the philosophical spaces overlap. Being too wise and too good to avenge the looting of her home by the giant intruders, also animal characters, and standing in the way of her new fledging generation

\footnotetext{
${ }^{10}$ Aggadah is Hebrew for Jewish folklore.

${ }^{11}$ al-Nakba, an Anglicized Arabic term for mass catastrophe used to describe the Palestinian exodus from Palestine into the Arab neighboring countries and elsewhere due to the Jewish settlers overuse of force and violence against the Arab civilians of Palestine who fled their homes and property and became homeless, refugees and stateless.

12 The fables of Kalila wa Dimna were written by the Abbassid story teller and translator, Ibn alMuqaffa'. The fables use animal characters as a vehicle carrying the writer's vision about life where the artistic, the mental, the narrative, the moral and the philosophical spaces overlap.
} 
that flames up with rage trying to restore home by force, Mother Hen resorts to wisdom as she addresses her impatient chicks:

You've got no choice but to disperse across the world and preach the value of virtue and convince the aggressors that their aggression won't pay off. Only then would you be able to resolve a larger problem of which yours is only part ... and I'm pretty sure that we shall meet again in this very home after we have purified the world from those who strayed away from the right path (El-Husseini 1943: 153, 157). [translation mine]

Although this Mother Hen is quite aware of the fatal danger threatening to exterminate her very existence, she resorts to moral philosophy as a way to combat a well-armed and logistically mobilized intruder. It is quite meaningless and absurd on the part of El-Husseini to try to resolve a big national problem in that way, for such an attempt would be readily dismissed as romantic nonsense, if not classified as a document of high treason. Although allusive and indirect to avoid the censorship of printed matter by the British Mandatory authorities in Palestine then, the fable does imply one thing at best; it justifies defeat by accepting armed-to-teeth strangers as intruders whose terror against the local citizens reminds us of the European White Man's "geographical discoveries" 13 during the late $15^{\text {th }}$ and early $16^{\text {th }}$ centuries.

\section{The Pioneers}

The Palestinian pioneer story-tellers produced novels fashioned on the Western model of narrative art. Among them are Ghassan Kanafani, Emile Habibi, Anton Shammas, Sahar Khalifeh, to mention only a few. If compared to earlier story-tellers, Ghassan Kanafani, who was forced to leave his homeland at the age of 12, tells a different story. His first novel, Rijal fil Shams [Men in the Sun] which came out in Beirut in 1963, is a tragedy without a tragic hero. It is the story of three Palestinian refugees of different age groups (symbolically three generations: the elderly Abu-Qais, the young man Asaad, and the teen-age Marwan) who accept to be smuggled inside an empty watercarrying cistern across the Iraqi-Kuwaiti borders in pursuit of a crust of bread in a country where "a man can collect money in the twinkling of an eye ... and where the first thing you will learn is that money comes first, and then morals" (Kanafani 1978: 6, 28). Ironically, the three men are led by Abul-Khaizuran, an emasculated Palestinian refugee, who works as a water-tank driver for the Kuwaiti Sheikh Rida whose hobby is game hunting. Helplessly waiting for the slow bureaucratic paper work clearance to be done at the Kuwaiti borders, the three men perish inside the cistern under the scorching sun of August. Nonchalantly, the driver drives the lorry into the desert and pulls over to a garbage heap where he dumps the three corpses after stripping them of their personal possessions, including their identification papers. In an attempt "to

13 Reference is made to the European geographical explorations of waterways to India inaugurated by Christopher Columbus in 1492. 
shirk and shift responsibility for their cheap death and group punishment" (Hussari 1993: 186), the smuggler blames it on the dead bodies for not having knocked on the burning sides of the metallic water-tank: "Why didn't you knock on the sides of the tank? Why didn't you say anything? Why? Why? Why?" (Kanafani 1978: 56). The symbolic association between the tightly-closed water tank and the Palestinian refugee camp as an enclosure does not lend itself to further interpretation.

Upon its first publication in Arabic, the tale was received with a shock. Some critics, who may have invested much on the rising wave of the Arab Nationalistic Movement (Nasserism) at the time, accused Kanafani of being a skeptic who threw the hopes of three Palestinian generations onto a desert garbage heap. Is it there that Palestinian runaways, with shattered personal dreams, should be thrown away as anonymous, no body? Artistically, however, Kanafani's ingenious blend of the symbolic and the realistic does save the tale from falling into the documentary, as he sacrifices neither of the two in the interest of recording a historical reality. In Rijal fil Shams, it is Kanafani the artist, not the politician and the journalist which he was, who compels the Palestinian refugees to voice themselves and seek other possibilities, in order to recover their national identity and defend their natural human rights before they are ambushed, as individuals seeking personal gains, and perish silently into oblivion. The last scene of the tale, though too tragic to be tolerated, says it all.

In his second novel, Ma Tabaqqa Lakum [All That's Left to You] which came out in 1966, Kanafani, influenced by William Faulkner's narrative technique in The Sound and the Fury (1929), creates a young would-be hero, Hamid, out of despair and disgrace. It is the story of a brother and sister living in Gaza as refugees and separated from their mother, also a refugee whose husband was shot in Jaffa in 1948 and she is now assumed to be living in the West Bank which was annexed to the Kingdom of Jordan after 1948. The story illuminates the inextricable issues of family and land, and the rage over their loss. Feeling ashamed of his elder sister being sexually disgraced by a Palestinian collaborator, Hamid reluctantly accepts to marry off his pregnant sister to Zakaria the collaborator for no dowry, and decides to cross the Naqab Desert between Gaza Strip and the West Bank for a family reunion. It is in the desert, which Kanafani personifies as an animate character, that Hamid feels at home and accidentally ambushes an isolated Israeli border guard and seizes his gun. At the same moment, his sister Mariam recounts her disgrace and realizes that her husband is none but the enemy of the people. Separated by age and distance, Hamid and Mariam are now united in a common struggle: one facing the enemy within, the other the enemy without. Interestingly enough, however, as the story progresses at a quicker pace, Hamid and the hostage Israeli soldier seem to be going around in a vicious circle. Only then does Hamid try to initiate a "conversation" with his hostage, but to no avail, for the language used does not seem to serve their one-way communication:

Perhaps you only know Hebrew, but that doesn't matter. But really, isn't it amazing that we should meet so dramatically here in this emptiness, and 
then find that we can't communicate? He went on looking at me, his face dark and hesitant and somewhat suspicious, but there was no doubt he was afraid. As for me, I'd crossed the barrier of fear, and the emotions I was feeling were strange and inexplicable ... All I intended to do was make it clear to him that there was nothing that merited his interest, that I wasn't harboring any concealed plan, and that if necessary we'd sit there until ... until what? (Kanafani 1990: 35, 47).

In light of the real power struggle between the Palestinians and the Israelis before 1967, Hamid's attempt to start a dialogue with the Israeli soldier would have been considered unripe and ineffective, but not in the least futile. In $M a$ Tabaqqa Lakum, Kanafani scores an advantage over all earlier Palestinian narratives as regards the issue of national identity as well as the moment of truth that culminates in the face-to-face encounter between Palestinian natives and Jewish settlers on the one hand, and Palestinian patriots and their countrymen collaborators on the other. Nothing could be more telling than that symbolic moment of revelation when the voices of Hamed and Mariam, each fighting their own battle, fuse into each other despite the distance that separates them. The moment Hamed ambushes the Israeli soldier and is ready to slit his throat as an intruder, is the same moment Mariam plunges her kitchen knife in the loins of her husband Zakaria as a collaborator and enemy of the people. Only then does Kanafani's art of fiction in this novel succeed to define the birth-right parameters of national identity and belonging.

Unlike Kanafani, who wrote stories about Palestinian refugees in the remaining parts of their land and in exile, Emile Habibi, who was lucky enough to remain in his city Haifa after the 1948 exodus, wrote stories about the Palestinians from inside the newly established state of Israel. Habibi's masterpiece, for short al-Mutashael [The Secret Life of Sa'eed, the Ill-Fated Pessoptimist] which came out in 1974 is a series of tragicomic episodes, reported in the epistolary style of narration and addressed by Sa'eed, the pessoptimist, who is mounting the back of an outer space creature, to someone on earth for publicity. The events unfolded cover a span of almost twenty years (1948-1967) in the life of a Palestinian who returns to his city, Haifa, soon after discovering with thousands of other Palestinians forced to flee their homeland that they would become refugees in the neighboring countries. Having successfully infiltrated back into his own birthplace, Sa'eed chooses to collaborate with the occupation forces for his personal safety. He gradually, however, works against all the odds to transform himself from a mean informer for the Zionist state into a simple man who only needs to survive. His story -feeding on fact and fantasy, tragedy and comedy -- uncovers the contradictions deriving from the dynamics of the various situations he finds himself in as he unwillingly fills the distance between the pioneer settler Zionists and the Palestinian resistance fighters. Failing to redeem himself or pay it some homage, despite the two heroic situations which might have elevated him (namely the heroic death of his wife and son, and his imprisonment as enemy of the state), Sa'eed also fails to belong or fit. Unable to restore his former 
despicable role as collaborator or join the struggle for a greater cause, Saeed is caught in the trap of his own impotency. Only then does he choose to escape into the miraculous and the fantastic for salvation, which is denied him on earth. Sitting on a symbolic stake, and not responding to the calls of various people (including the apologetic Israeli secret police officer - the Big Man), Sa'eed can only expect a miracle as a way out from this terrible situation.

\author{
"My master!" I shouted, "chief of all those of outer space, \\ I have no one but you!" \\ "I know that," he replied. \\ "You came just in time." \\ "I only come to you just in the nick of time." \\ "Save me, reverend," I pleaded. \\ "I just wanted to say to you: this is the way you always are. \\ When you can bear the misery of your reality no longer \\ but will not pay the price necessary to change it, only then \\ you come to me..." (Habibi 2002: 159).
}

By using an outer space creature, supposedly a mythical deliverer, Habibi seems to be parodying the Greeks and Romans who used deus ex machina as a theatrical device to save the tale from reaching an inevitable deadlock. His use of this supernatural agency is in no way a matter of begging deliverance. The frequent reference to the Savior (the Christ) and Al-Mahdi (the long-awaited) is highly ironical. As the story opens and ends with the outer space creature commenting on Saeed's difficult situation, it also allows this black comedy to expose the sordid reality engulfing the life of the Palestinian people on earth. It seems that for the Palestinians to voice themselves in a maddening world devoid of mercy and justice, they need the job to be done by some "divine intervention" -- to use the title of the Palestinian Elia Suleiman's film, which is also a black comedy. However, Sa'eed is in no wise a defeatist, indolent hero. Like Voltaire's hero in Candide, Sa'eed uncovers much for us to discover more about what it means to be a Palestinian exiled in his own country by an oppressor whose main concern is masked behind the claim of "national security". If Sa'eed does not measure up to be a hero in the traditional sense of the term, the tale does by all means hint to heroic nuances, among which the derision of tolerance as an absurd human value vis-à-vis occupation as well as the exposing of Israel as an ethnic and false democracy in the Middle East. It is by defining the Israeli other as an armed-to-teeth settler and victimizer of the native Palestinian that Sa'eed succeeds to define himself as an outlaw in his own land. Power relations are part and parcel of the process of his definition of identity politics.

Habib's vision is exclusively focused on Sa'eed, a prototype for a passive fictional character, who, despite all the concessions he keeps making to the Israeli security people, fails to adapt to the new realities conditioned by the creation of the state of Israel. In an interview with literary critic Radwa Ashour, Habibi says, "I've chosen for my story a character with many defects 
which I need to expose in the first place" (Ashour 1978 qtd. in Filistin aThawra 34, my translation). Among Sa'eed's defects are cowardice, meanness, opportunism, and collaboration with the enemy, to mention only a few. For instance, deciding to visit his own house being occupied by the new European Jewish settlers, Sa'eed says:

When I reached the front of our house and saw laundry hanging out, my courage deserted me and I pretended to be taking a stroll along the seashore (Habibi 2002: 47).

Tolerating the de facto situation that could have never been any better, the Panglossian Sa'eed admits that, "Anyone who marries my mother becomes my stepfather" (Habibi 2002: 49). Unable to harbor any clear plan whatsoever, his opportunistic attitude shows him as an insect on the wing, ready to land anywhere as he straddles the borderline between what is and what could be:

I was impressed by the Jewish workers' ignorance of Hebrew that I decided that this state [Israel] was not fated to survive. Why should I not therefore protect my line of retreat? (Habibi 2002: 50).

And above all that, he still keeps "a clear conscience" (Habibi 2002: 66).

It is in Habibi's smart use of irony, which multiplies at crucial moments, that the story goes beyond Sa'eed as a fictional character to embrace the national cause of the Palestinian people. Habibi borrows Sa'eed's penetrating eye-sight, which excludes no detail, to scratch beneath the surface of reality and uncover all the sordid events in the life of his people. The journey taken by Sa'eed from the very outset of the tale is a search for a roadmap to restore identity. The harsher reality slaps him in the face, the further Sa'eed goes into that search. Even compromising a way out from several dilemmas is part of Sa'eed's tactics to keep himself visible as an Arab Palestinian minority in Israel today.

In the final scene, "The Glorious Finale," Sa'eed is seen climbing on the back of the creature from the outer space, beneath him down on earth "the sound of joyful ululation" (Habibi 2002: 159). Among others, there is the bornin-exile Yu'aad (the returnee) whose visit permit to see her next of kin has been cancelled - she being deported by the Israeli military rule:

Finally, there was Yuaad. As she raised her head to the sky and pointed to us [Sa'eed and the outer space creature], I heard her say, "When this cloud passes, the sun will shine once more!" (Habibi 2002: 160).

If there is any message created through the outer space creature episode at all, it could be anything within the satirical mode of narration except for the idea of salvation. Habibi seems to have created this superstitious means to an imagined salvation only to refute it once and for all, be it part of a religious 
myth or otherwise. The outer space creature, as the long-awaited savior, does not exist except in the minds of the dervish-minded communities whose indolent nature cannot be inventive for a big change. Habibi made this crystal clear in the epilogue that closes the tale.

With Anton Shammas writing as an insider, the ball is kept rolling but this time it is moved further into the Israeli circle of intelligentsia. Arabesques (1986), his semi-autobiographical novel, is "a Palestinian tale in Hebrew letters" (Amit 1988: 73) and "a text written in the language of the conquerors" (Hever 2002: 176). Addressed to the Hebrew-speaking readers in the first place, the tale places Israeli liberal doves in an uneasy position, for it "questions their cultural assumptions and expectations" (Hever 2002: 176). Defining his position as author of and character in the tale, Shammas harbors no clear plans as to who he really is, for he tries to coin his identity as a hybrid product of a de facto complex situation. This is where he stands: between a personal memory recollected from oral tales about his origin as an Arab Palestinian, and a futuristic vision he is trying to crystallize as a non-Jewish Israeli citizen. The novel was severely criticized by his Arab and Jewish reviewers alike (see Darwish 1996, Grossman 2003, Marzorati 1988).

In an interview with Daliyah Amit, and perhaps in response to the Israeli critic and novelist, A.B. Yehoshua, who advises him "to pick up his belongings and move a hundred meters east, to the becoming Palestinian nation where he could realize his Palestinian identity fully" (Amit 1988), Shammas says, "What I'm trying to do is to un-Jew the Hebrew language ... to bring it back to its semantic origins, back to its place" (Amit 1988: 75) [emphasis mine]. UnJewing the Hebrew language would simply mean breaking one leg of the tripod upon which the Zionist project rests. As laid down by Herzl and other Jewish leaders, Zionist nationalism interlocks identity, homeland, and language. To write in Hebrew, Shammas adds, "[this] requires a lot of chutzpah ${ }^{14}$ [which] I didn't bring from my childhood village. There is no chutzpah there. I borrowed it from other places" (Amit 1988: 76). Azmi Beshara (2005), an ex-member of the Israeli Knesset (parliament), refers to chutzpah, a Hebrew word, which indicates full assimilation into the Jewish cultural space.

Arabesques invited much criticism in Israel, not only by Israeli critics who laced into the novel as a non-Jewish narrative undermining their national assumptions, but also by Israeli writers who feature in the novel as characters debating with Shammas about his using the Hebrew language to write a nonHebrew story. Besides Yehoshua, many other moderate liberal Israeli writers, including Amos $\mathrm{Oz}$ and David Grossman, made responses:

I think of [the publication] as a triumph ... not for the Israeli society, but for the Hebrew language. If the Hebrew language is becoming attractive for a non-Jewish Israeli to write in, then we have arrived! (Oz $1987 \mathrm{qtd}$ in Hever 2000).

\footnotetext{
${ }^{14}$ Chutzpah is a Hebrew word meaning full integration into the Jewish language and culture in which Hebrew is used as a medium of everyday communication.
} 
... invited into the language, the guest [Shammas] already begins the process of conquering (Grossman 2003: 194).

Deriving its name and structure from arabesque, an elaborate and fanciful design of twisted shapes, geometrical figures, and so forth, the novel is a tedious search for identity in two parts, each of which informs a little about the other. The first part recalling the author's family is history retrieved for honesty of record; the second part recording the author's journey to the United States, as participant in a cultural activity, is an attempt to redefine his present ambivalent identity through debate. Still in the eyes of other characters, Shammas is a "sample Arab", whom Yehoshua Bar-On, an Israeli writer and character in the second part of the story, offers salvation through the Hebrew language which he refers to as a sanctified territory that cannot be transgressed.

My Arab [Shammas] will build his confused tower on my space, in the language of grace. That is his only possible salvation (Shammas 1988: 8283). [Emphasis mine.]

Shammas does not continue shaping his national identity in the second part of Arabesques; instead, he dissolves the self into the animation of the story of others. For Shammas, the Hebrew language, as a cultural space, does exclude and discriminate against its non-Jewish users. In this respect, Shammas does not stand alone. Mahmoud Darwish, the Palestinian poet who was born in Palestine and lived in Israel afterwards but died in exile, sees Hebrew as "my language of love and friendship ... the language of my childhood memories" (Darwish 1996: 195).

Trying to compromise his position vis-à-vis the question of identity, Shammas does not seem to have garnered support for using the Hebrew language as a vehicle of the minority discourse. Renouncing his Arab Palestinian identity and hoping to liberate his Israeli identity from its Jewishness, Shammas stands in no man's land.

Once again, I find myself standing at the entrance of the big gate. My life followed the path of a winding arabesque that has led me to the very same place where I began my journey (Shammas 1988: 203).

By appropriating the Hebrew language as a common cultural space between the Jewish majority and the Palestinian minority to serve an imaginative solution of identity, Shammas admits that he has adamantly transgressed a Jewish territory. His endeavor seems to have been provocative enough even to those Israeli doves who pretend that the Jewish Israelis, alone, are the owners of Hebrew as the first national language of the state of Israel. His attempt, however, cannot be dismissed as meaningless. He is fighting his battle on the same ground the Jewish Israelis claim it is theirs. Using their Hebrew language to pass a clear-cut message about identity and citizenry, Shammas is viewed as a conqueror of the Jewish sanctity in which none is 
allowed to enter. Although identity is not a subject to be compromised, Shammas takes the risk of doing that, testing the tolerance of the Israeli liberal doves whose reaction turns out to be ironically hawkish.

\section{National Identity or National Allegory?}

Fredric Jameson (1986) posits the reading of Third-World literature as a form of national allegory. Unlike the case in Western Literature which Jameson sees as global in culture, Third-World literature "has a tendency to remind us of outmoded stages of our development" (Jameson 1986: 65). His conception of the third-world national allegory is based on the assumption that "the story of the private individual destiny is always an allegory of the embattled situation of the public third-world culture and society" (Jameson 1986: 69). That is, the personal is the national; the story of the individual hero is always the story of the nation, for the narratives project a national political dimension, which is not the case in Western literature. Jameson's sweeping generalization cannot stand an objective test when it comes to the particular drama of the Palestinian people whose fate, as a nation, has been at stake for almost a century. The realistic stories depicting this public drama and that traumatic situation can in no way touch the level of allegory. Despite some variations peculiar to each story, all the novels attempted in this article feature a historical phase, in which all the Palestinians, none excepted, were facing the same dark fate: an existential threat and loss of national identity. As a nation, and not as individual heroes or case-studies, the Palestinian civilians were all forced out of their homeland into nowhere. National identity is not the prerogative or the concern of individual citizens or characters in stories. It is something public, and it concerns the whole nation. If Jameson sees the issue of national identity in terms of national allegory, it is probably because the individual hero (where there is one) is meant to represent the nation under Western colonization and/or direct external threat.

\section{Conclusion}

For the past hundred years, the Palestinian people, both in their homeland and in exile, have been making narratives that would tell about who they were and are in space and time. Although those narratives are distinct in scope, subject matter, and the themes attempted, it should be noted that they have undergone a gradual line of perception in the area of developing, shaping and representing their national identity. The stories examined in this article show that there is a remarkable shift in the way those writers have represented the issue of identity; that is, from the romantic to the realistic, from the egoistic to the altruistic, from the individualistic to the communal way of life, not way of living. The Palestinians have been trying to tell their own side of the story, the long-denied version of the truth, the hidden part of the historical narrative in 
which the fates of Arabs, Jews and other ethnic groups are enmeshed. More particularly, the Palestinian novelists who tell their own narratives also manage to adjust the focus of others' vision on their visibility as a people who have always been there. If the places from which they have been writing are distinct, and if critical reviews of their works have often polarized their voice, the shift from alienation to initiation as an issue permeating most of their narratives seems to have enabled them to show a strong sense of visibility. It is the "We" standing out against the "I" that levels out their distinctions of origin (see also Edward Said 1999, Hisham Sharabi 1978, and Salma Jayyusi 1997. It is the Palestinian authentic voice that is more audible now than phrases like "the Arab of the interior," "the Israeli Arab," "the Jew of the Jews," or "the refugee" which until recently have been the most common labels signifying the Palestinian. As tellers of their own narratives, the Palestinians have invariably voiced themselves on the platform of the Middle East in the battle of discourses and identity politics.

\section{Acknowledgments}

This article is originally an academic conference paper presented at the ATINER $9^{\text {th }}$ Annual International Conference on Literature, 6-9 June, 2016, Athens, Greece. I hereby express my gratitude to Dr. Zoe Boutsioli, Director of Publication, and to the two knowledgeable reviewers for their valuable notes based on expertise and professional reading of the article.

\section{References}

Amit D (1988) Re'ayon im Anton Shammas (An Interview with Anton Shammas). Proza: 73-78.

Ashour R (1978) Muqabalah ma' Emile Habibi (Interview with Emile Habibi). Filistin a-Thawrah 254(2/October).

Baidas K (1920) Al-Warith (The Inheritor). Al-Quds: Dar el-Aytam el-Souriyya.

Beshara A (2005) Hob fi Mantiqat el-zil: riwayat shazaya makan (Love in an Area of Shadows: a tale of a place fragmented). Beirut: Arab Cultural Center.

Darwish M (1996) Interview with Hilit Yeshurun (in Hebrew). Chadarim: 194-195.

Grossman D (2003) She-tehi li ha-Sakin (Be My Knife), Translated from Hebrew by Vere Almog \& Maya Gurantz). N.Y.: Bloomsbury.

Habibi E (2002) The Secret Life of Saeed the Pessoptimist, Translated from the Arabic by Salma. K. Jayyusi \& T. Legassick, 1985). N.Y.: Interlink Books.

Harshav B (1993) Language in Time of Revolution. Stanford: Stanford University Press.

Hever H (2002) Producing the Modern Canon: nation building and minority discourses. New York and London: New York University Press.

Hussari (El), I (ed.) (1993) Studies in World Literature: The Modern Novel. Beirut: Modern Library for Printing \& Publishing.

Husseini (El), Is-haq (1943) Muzakkarat Dajaja (Memoirs of a Mother Hen). AlQahira: Maktabat al-Ma'aref. 
Jameson F (1986) Third-World Literature in the Era of Multinational Capitalism. Social Text 15 (Autumn): 65-88.

Jayyusi SK (1997) On the Elusive Chord of Memory: Remembering Acre. Unpublished essay.

Kanafani G (1990) Ma Tabaqqa Lakum (All That's Left to You). Translated from the Arabic by May Jayyusi \& Jeremy Reed. Austin, Texas: Center for Middle Eastern Studies.

Kanafani G (1978) Rijal fil Shams (Men in the Sun). Translated from the Arabic by J. Kilpatrick. London: Heinemann Arab Authors.

Marzorati G (1988) An Arab Voice in Israel. The New York Times, September 18. Retrieved from http://goo.gl/yolGcG.

Oz A (1987) Interview with Hannan Hever. Quoted in Cultural Critique, No. 7. The Nature of Minority Discourse 11 (Autumn, 1987): 47-76.

Pappe I (2006) The Ethnic Cleansing of Palestine. Oxford: Oneworld Publications, 2006.

Peleg Y (2005) Love at First Sight? David, Jonathan and the Biblical Politics of Gender. Journal of Studies of the Old Testament 30(2): 71-189.

Said EW (1979) Orientalism. New York: Vintage Books.

Said EW (1999) Out of Place: A Memoir. London: Granta Books.

Shammas A (1988) Arabesques. Translated by Vivian Eden. New York: Harper \& Row.

Sharabi H (1978) Al-Jamr wa-al-Ramad: Dhikrayat Muthaqqaf Arabi (Embers and Ashes: Memoirs of an Arab Intellectual). Beirut: Dar al-Tali'a.

Suleiman E (Dir.) (2002) Divine Intervention. Produced by Humbert Balsan \& Elia Suleiman, May 19.

Wadi F (1981) Thalath Alamat fil riwaya al-Filistiniah: Ghassan kanafani, Emile Habib iand Jabra Ibrahim Jabra (Three Lanmarks in the Palestinian Novel). Beirut: Munazamat Atahrir el-Filistiniah - da'erat el-I'lam wathaqafa.

Yehoshua AB (2007) Being Israeli (a speech delivered at the opening of the centennial celebration of the American Jewish Committee. Jerusalem Post, 25 January. Retrieved from http://goo.gl/hFBoUc. 